\title{
Photographic assessment of overstory and understory leaf area index in beech forests under different management regimes in Central Italy
}

\author{
Short communication
}

\section{Francesco Chianucci*, Nicola Puletti, Ernesto Venturi, Andrea Cutini and Ugo Chiavetta}

Chianucci, F., Puletti, N., Venturi, E., Cutini, A., Chiavetta, U. 2014. Photographic assessment of overstory and understory leaf area index in beech forests under different management regimes in Central Italy. - Forestry Studies | Metsanduslikud Uurimused 61, 27-34. ISSN 1406-9954. Journal homepage: http:/ / mi.emu.ee/forestry. studies

\begin{abstract}
Forest understory may be strongly affected by silvicultural practices such as thinning, which simultaneously modulates the overstory canopy cover and influences the availability of light. However, the understory layer is rarely considered in management decisions, partly because methods to estimate understory leaf area index are poorly developed. In this study we used two different restricted view angle photographic methods to estimate overstory plant area index $L_{O}$ (zenith cover photography), understory leaf area index $L_{U}$ (nadir cover photography) and their related canopy attributes (foliage clumping, foliage cover, crown cover, crown porosity). These measurements were performed in beech stands under different management regime. Results from photography indicated that not only overstory but also understory canopy attributes were significantly influenced by forest management. In addition, a significant negative correlation was found between $L_{O}$ and $L_{U}$. We conclude that the photographic methods are effective for monitoring (overstory and understory) canopy status in managed stands, on account of their rapid and not destructive procedures, which allows large scale implementation of the methods.
\end{abstract}

Keywords: forest understory, plant area index, thinning, Fagus sylvatica, cover photography.

Authors' address: Consiglio per la Ricerca in Agricoltura e l'Analisi dell'Economia Agraria - Forestry Research Centre, Viale Santa Margherita 80, 52100 Arezzo, Italy; *e-mail: fchianucci@gmail.com

\section{Introduction}

Managing forests in ways that sustain biodiversity and ecosystem functioning is a major challenge in modern forestry. As forest management consists of a complex of anthropogenic disturbance, silviculture should be a key factor in explaining plant distribution and diversity in managed forests (Decocq et al., 2004). In particular, for- est understory - i.e., the vegetation growing beneath the forest canopy, may be strongly affected by silvicultural practices such as thinning, which simultaneously modulates the (overstory) canopy cover and therefore the availability of different resources, including light, water and soil nutrients (Decocq et al., 2004; Coll et al., 2011). The forest overstory-understory relationships are complex and mutual, but 
are dominated by the strong influence of the overstory structure on e.g. litter, light availability and quality (Messier et al., 1998); hence, overstory canopy structure may play a key role in understory recruitment, establishment, and thus plant diversity. However, studies reporting overstory-understory relationships rarely describe the relationship in terms of leaf (or plant) area index, which is a key canopy attribute. This is mainly motivated because, although methods for estimating overstory leaf area index have received considerable attention in the last decades (for a review, see Bréda, 2003; Jonckheere et al., 2004; Chianucci \& Cutini, 2012), their application in understory remains largely unexplored (Kodar et al., 2011; Chianucci et al., 2014b). Visual observations methods such as the BraunBlanquet scale (1964) provide highly subjective estimates, which severely hamper comparisons among studies; in addition, such methods are unable to provide leaf area index (Macfarlane et al., 2010). Accurate measurements of understory leaf area index are also required for radiative transfer modeling and for calibrating remotely-sensed data (e.g. Kuusk et al., 2004; Peltoniemi et al., 2005; Eriksson et al., 2006; Rautiainen et al., 2011; Pisek et al., 2015).

Recently, Chianucci et al. (2014b) proposed a combination of digital photographic methods to obtain rapid, reliable and non destructive estimates of leaf area index of understory. Unfortunately, their measurements were limited to three deciduous species and were not applied at site level; also, the authors were unable to compare overstory and understory leaf (or plant) area index estimates at the time.

In this study, we tested two different, restricted-view angle photographic methods to estimate overstory plant area index and understory leaf area index and their related canopy attributes (crown cover, foliage cover, crown porosity and foliage clumping of the two layers). These methods were applied in beech stands under different management regimes to explore their effectiveness for monitoring the overstory and understory canopy status in differently treated stands.

\section{Materials and methods}

\section{Study area}

This study was conducted in a mountainous area of central Italy (Alpe di Catenaia; $43^{\circ} 49^{\prime} \mathrm{N}$; $11^{\circ} 49^{\prime} \mathrm{E}$ ), which is representative of typical forest systems in the northern and central Apennines. The climate in this area is temperate with warm, dry summers and cold, rainy winters. The mean annual rainfall was $1,164 \mathrm{~mm}$ and the mean air temperature was $9.3^{\circ}$.

The study included three permanent research plots established in a previous study in 1972 (Cutini et al., 2015). The plots were located at an altitude of about 1,100 $\mathrm{m}$, with an average slope of $15 \%$ and a South-West exposure. All the plots consisted of pure beech coppice stands 67 years old under conversion to high forests either by natural evolution (hereafter TEST) or by two active management options: periodic thinning and seed cutting, as described below. In the periodic thinning plot (hereafter THIN), three low thinnings of mediumheavy intensity were carried out in 1972, 1987 and 2002, which reduced standing basal area by $44 \%, 38 \%$ and $29 \%$ respectively, with the last thinning reducing overstory plant area index by $27 \%$ (from 5.66 to $4.13 \mathrm{~m}^{2} \mathrm{~m}^{-2}$ ) in 2002 (Cutini et al., 2015). A more intensive option was adopted in the other plot (hereafter SEED), where two low thinnings of medium-heavy intensity (comparable to those carried out in periodic thinning plot) which were done in 1972 and 1987, were followed by an advance seed cutting in 2002, a regeneration cutting that reduced basal area by $56 \%$ and overstory plant area index by $79 \%$ (from 5.17 to $1.11 \mathrm{~m}^{2} \mathrm{~m}^{-2}$ ) in 2002 (Cutini et al., 2015). A previous study conducted in the research plots revealed that both overstory canopy 
Table 1. Main stand attributes of the research plots at two inventories $(1972,2012)$.

\begin{tabular}{ccccccc}
\hline $\begin{array}{c}\text { Silvicultural } \\
\text { treatment }\end{array}$ & $\begin{array}{c}\text { Stems } \\
(\mathrm{n} \mathrm{ha}-1)\end{array}$ & $\begin{array}{c}\text { Height } \\
(\mathrm{m})\end{array}$ & $\begin{array}{c}\text { Basal area } \\
(\mathrm{n} \mathrm{ha}-1)\end{array}$ & $\begin{array}{c}\text { Stems } \\
(\mathrm{n} \mathrm{ha}-1)\end{array}$ & $\begin{array}{c}\text { Height } \\
(\mathrm{m})\end{array}$ & $\begin{array}{c}\text { Basal area } \\
\left(\mathrm{n} \mathrm{ha} \mathbf{H}^{-1}\right)\end{array}$ \\
\hline SEED & 6120 & 11,2 & 24,1 & 108 & 30,5 & 19,9 \\
THIN & 7407 & 11,2 & 27,5 & 412 & 26,4 & 29,8 \\
TEST & 7518 & 11,2 & 27,4 & 2046 & 26,7 & 48,2 \\
\hline
\end{tabular}

and stand structure were differently modified by the applied silvicultural practices in the long term (Cutini et al., 2015). Compared with unthinned control, the reduction in basal area and overstory plant area index was fully recovered in THIN after ten years from thinning. Conversely, the reduction in basal area and overstory plant area index after seed cutting was not fully recovered in SEED after ten years from seed cutting. This gave us the opportunity to evaluate whether the differences in understory are in agreement with those previously observed at overstory level (Cutini et al., 2015). Table 1 lists the main stand attributes in the research plots.

\section{Overstory and understory canopy attributes}

Overstory and understory canopy attributes were estimated using two digital photographic methods, respectively zenith cover photography (Macfarlane et al., 2007; Chianucci \& Cutini, 2013) and nadir cover photography (Chianucci et al., 2014b). All images were collected in August 2014 close to sunrise under uniform and calm conditions to prevent wind effect on the leaves. All images were collected using a Nikon D90 DSLR camera (Sendai Nikon Corp., Otawara, Tochigi, Japan) with the aperture set to f/8.0, automatic exposure, ISO 400, automatic white balance, maximum resolution and FINE quality JPEG.

Zenith cover images of overstory were collected on a grid of 9-15 sample points, which were located within each experimental plot. The camera was equipped with AF Nikkor $50 \mathrm{~mm} \mathrm{f} / 1.8 \mathrm{D}$ lens (mazimum zenith angle range of $0-15^{\circ}$ ) and pointed upward using a self-leveling tripod. Zenith cover images were analyzed in Winscanopy 2012 (Regent Instruments, Ste-Foy, Quebec, Canada). Foliage cover $\left(F F_{O}\right.$, i.e. the proportion of the ground area covered by the vertical projection of leaves and woody vegetation); crown cover $\left(F C_{O}\right.$, i.e. the proportion of pixels that do not lie in between-crowns gaps, which is equivalent to Nilson's (1999) canopy closure, but also see Jennings et al. (1999)), crown porosity $\left(C P_{O}\right.$, i.e. the proportion of sky within crown envelopes) and foliage clumping $\left(\Omega_{O}\right.$, i.e., the deviation from random distribution of foliage within the canopy) were estimated from a gap-size distribution approach (Chen \& Cihlar, 1995), considering gaps larger than $0.3 \%$ of the image area as between-crowns gaps; this gap size threshold was set based on visual image inspection. Plant area index $\left(L_{O}\right)$, including woody materials, was then calculated using an extinction coefficient of 0.85 , which was calibrated in a previous study from levelled photographic measurements of leaf inclination angles (Chianucci et al., 2014b):

$L_{O}=-\frac{\ln \left(1-F F_{O}\right)}{0.85 \times \Omega_{O}}$, where

$\Omega_{O}=\frac{\left(1-C P_{O}\right) \times \ln \left(1-F F_{O}\right)}{\ln \left(C P_{O}\right) \times F F_{O}}$ and $C P_{O}=1-\frac{F F_{O}}{F C_{O}}$. 
Nadir cover images of understory were collected for each plot at the same grid of overstory images; four images were collected and averaged per each grid point for a total of 36-60 images per plot. The camera was equipped with AF Nikkor 18 $\mathrm{mm} \mathrm{f} / 2.8 \mathrm{D}$ lens (maximum zenith angle range of $0-50^{\circ}$ ) and was attached to the top of an extendable $2-10 \mathrm{~m}$. pole via an angled steel bracket such that the camera pointed downward when the pole was held at arm's length with the base of the pole between the operator's feet. Depending on the pole's extensions, images were acquired from a height of 3-4 $\mathrm{m}$ above the ground. Understory foliage cover $\left(F F_{U}\right)$ was estimated from two nadir image classification methods, namely LAB2 and Rosin (Macfarlane \& Ogden, 2012) as briefly described below.

LAB2 classification method combines pixel chromaticity information (the $a^{*}$ and $b^{*}$ coordinates of CIE $L^{*} a^{*} b^{*}$ color model of Mclaren (1976), whose coordinates represent the lightness of the color $\left(L^{*}\right)$, its position between red/magenta and green $\left(a^{*}\right)$ and its position between blue and yellow $\left(b^{*}\right)$ ) and a vegetation index (GLA = 2G-R$B / 2 G+R+B$, where $G, R$, and $B$ represent the green, red and blue channel of the image, respectively) to classify foliage cover (for detail, see Macfarlane \& Ogden, 2012); Rosin is an histogram-shape based classification method which detects the point of maximum curvature on a L-shaped curve by fitting a straight line from the maximum to the last non-empty bin of the histogram curve. Both the two nadir image classification methods are largely automated. The greatest disadvantage of the method was that post-analysis quality control is still required: indeed, as previous studies demonstrated (Macfarlane \& Ogden, 2012; Chianucci et al., 2014b) LAB2 method should be used for estimates of $F F_{U}>0.1$ while Rosin should be used for estimates of $F F_{U}$ $<0.1$. To avoid subjectivity, when $F F_{U}$ estimates from Rosin where $<0.1$ we adopted Rosin method, and we adopted LAB2 method the way round. The classified images were then processed in Winscanopy for calculation of foliage clumping; gaps larger than $3 \%$ of the image area were considered as non random gaps (Chianucci et al., 2014a) and included in the calculation of understory foliage clumping $\left(\Omega_{\mathrm{U}}\right)$. Leaf area index $\left(L_{u}\right)$ was then calculated (Eq. 1) assuming an overall planophile distribution of understory plants (average extinction coefficient of 0.85 over $0-50^{\circ}$ angle range), based on field observations. The contribution of woody elements was considered negligible for downward-looking images.

Additional surveys were conducted in August 2014 to characterize understory diversity. Three $300 \mathrm{~m}^{2}$ understory plots were randomly established within each plot. The vascular plants were identified and its cover-abundance was estimated using the Braun-Blanquet scale. Subsequently, the cover-abundance values were transformed according to the ordinal scale proposed by Van Maarel (1979) for calculation of diversity indices. Understory diversity was calculated as species richness (SR, i.e., the total number of understory species present in the survey) and Shannon index $\left(\mathrm{H}^{\prime}\right)$ :

$H^{\prime}=-\sum_{i=1}^{s} p_{i} \ln \left(p_{i}\right)$

where $p_{i}$ is the proportion of the individuals found in the $i$ th species and $s$ is the number of species.

\section{Results}

The studied stands showed different overstory and understory canopy attributes, as a consequence of the different silvicultural treatments applied (Table 2). Overstory canopy density (i.e. foliage cover, crown cover and plant area index) was significantly lower in SEED compared with the other silvicultural options (Kruskal-Wallis test, $p<0.01)$. 
Table 2. Mean and standard error (brackets) of crown cover $\left(\mathrm{FC}_{0}\right)$, foliage cover $\left(\mathrm{FF}_{0}\right)$, crown porosity $\left(\mathrm{CP}_{0}\right)$, foliage clumping $\left(\Omega_{0}\right)$ and plant area index $\left(L_{0}\right)$ of forest overstory and leaf area index of forest understory $\left(L_{u}\right)$. Canopy attributes not sharing the same superscript letter are significantly different at the 0.01 level (Kruskal-Wallis).

\begin{tabular}{ccccccc}
\hline Plot & $F C_{0}$ & $F F_{0}$ & $C P_{0}$ & $\Omega_{0}$ & $L_{0}$ & $L_{u}$ \\
\hline SEED & $0.84(0.04)^{\mathrm{a}}$ & $0.78(0.04)^{\mathrm{a}}$ & $0.07(0.01)^{\mathrm{a}}$ & $0.72(0.05)^{\mathrm{a}}$ & $4.57(0.20)^{\mathrm{a}}$ & $0.98(0.07)^{\mathrm{a}}$ \\
THIN & $0.97(0.01)^{\mathrm{b}}$ & $0.92(0.01)^{\mathrm{b}}$ & $0.05(0.00)^{\mathrm{a}}$ & $0.90(0.02)^{\mathrm{b}}$ & $5.85(0.11)^{\mathrm{b}}$ & $0.45(0.07)^{\mathrm{b}}$ \\
TEST & $0.98(0.00)^{\mathrm{b}}$ & $0.92(0.01)^{\mathrm{b}}$ & $0.06(0.01)^{\mathrm{a}}$ & $0.92(0.02)^{\mathrm{b}}$ & $5.66(0.16)^{\mathrm{b}}$ & $0.44(0.05)^{\mathrm{b}}$ \\
\hline
\end{tabular}

Overstory foliage clumping decreased (i.e., canopy heterogeneity increased) as overstory leaf area was removed (Figure 1), with SEED exhibiting significantly lower $\Omega_{\mathrm{O}}$ values compared with the other silvicultural options (Kruskal-Wallis test, $p<$ 0.01). Conversely, no significant differences in overstory canopy attributes were observed between THIN and TEST plots after ten years from the last thinning (Table 2).

Understory plant area index was negatively correlated with overstory plant area index (Pearson's $r_{p}=0.67, p<0.01$ ); as a consequence, $L_{U}$ increased linearly as $L_{O}$ was removed (Figure 2), being significantly higher in SEED (Kruskal-Wallis test, $p<$ 0.01 ). Conversely, no significant differences in $L_{U}$ were observed between periodic

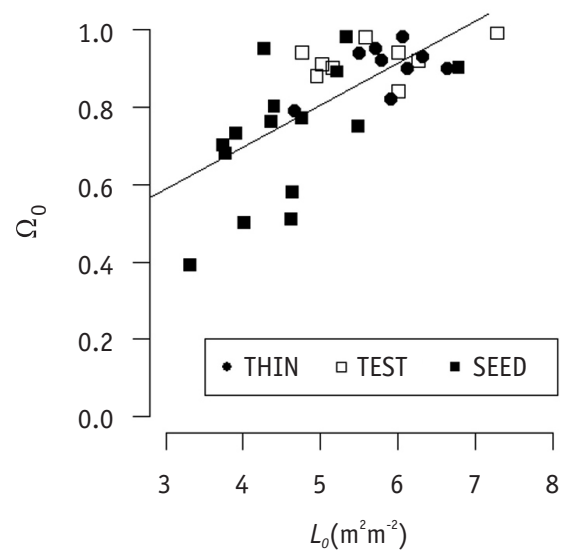

Figure 1. Relationship between foliage clumping index and plant area index of overstory calculated from digital photography. The linear model was $\Omega_{0}=0.11 L_{0}+0.26, \mathrm{R}^{2}$ $=0.50$, RMSE $=0.11$.
THIN and TEST plots after ten years from the last thinning (Table 2).

The differences in canopy attributes observed in the plots were in agreement with biodiversity indices (Table 3); the higher values were observed in the more intensive management option (SEED) while the lower values were observed in the unthinned control (Table 3). In SEED, 6 tree species out of a maximum of 22 plant species were recorded (Fagus sylvatica L., Quercus cerris L., Abies alba Mill., Prunus avium L., Salix caprea L., Pyrus pyraster L. Burgsd.); the average understory height was $1.5 \mathrm{~m}$ in that plot. In the other plots, the tree species observed were F. sylvatica and $Q$. cerris; the average understory height was $0.4 \mathrm{~m}$ in those plots.

Table 3. Mean and standard error (brackets) of species richness (SR) and Shannon index $\left(\mathrm{H}^{\prime}\right)$ in the studied plots.

\begin{tabular}{lcc}
\hline $\begin{array}{l}\text { Silvicultural } \\
\text { treatment }\end{array}$ & SR & $H^{\prime}$ \\
\hline SEED & $18.0(2.0)$ & $1.48(0.01)$ \\
THIN & $3.0(0.6)$ & $0.36(0.02)$ \\
TEST & $1.3(0.3)$ & $0.45(0.13)$ \\
\hline
\end{tabular}

\section{Discussion}

We quantified the overstory - understory relationship in terms of leaf (or plant) area index and its related canopy attributes. Importantly, a significant relationship between $L_{O}$ and $L_{U}$ was observed in the stud- 


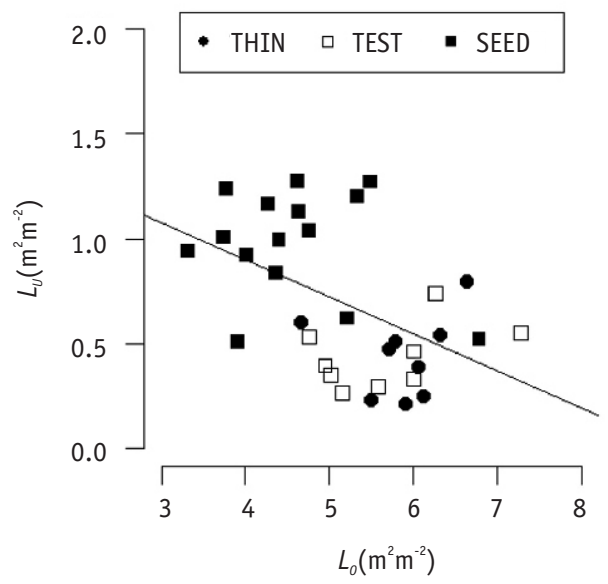

Figure 2. Relationship between $L_{u}$ and $L_{0}$ calculated from digital photography. The linear model was $L_{U}=-0.18 L_{0}+1.60, \mathrm{R}^{2}=$ 0.45, RMSE $=0.30$.

ied plots; the observed relationship $\left(L_{U}=\right.$ - $\left.0.18 L_{O}+1.60\right)$ was comparable with that obtained by Kodar et al. (2011) $\left(L_{U}=-0.21\right.$ $L_{O}+1.61$ ) in Järvselja (Estonia). Consistently with $L_{O}$ removal, $L_{U}$ was significantly higher in SEED plot, compared with the other surveyed management options. Conversely, no differences in both $L_{O}$ and $L_{U}$ were observed between THIN and TEST plots. Some studies have observed a response of understory to thinning (e.g. Borg \& Stoneman 1991; Lane \& Mackay, 2001), but these studies have not described such response in a quantitative manner. In addition, overstory and understory relationships have more frequently described as cover rather than plant area index of the two layers (Macfarlane et al., 2010). At another level, most of previous studies have focused on early response of understory to thinning (e.g. Decocq et al., 2004; Dodson et al., 2008); our observed overstory-understory significant relationship was observed after ten years from thinning, demonstrating the change associated to the silvicultural practices were not ephemeral, in agreement with previous reports (Cutini et al., 2015; Chianucci et al., 2015). Based on the results, we conclude that the proposed photographic methods are effective for monitoring overstory and understory canopy status in managed stands. Use of digital photography is desirable as the method is fast, cost-effective and not destructive (Lang et al., 2013), being therefore highly suitable for large scale, objective and broadly comparable measurements of understory and overstory canopy interactions, phenological studies, monitoring and research programs.

Acknowledgments. We thank the anonymous reviewers for their helpful comments. Francesco Chianucci was supported by the research grant "Relationship between stand structure and biodiversity in forest ecosystems - ForBIO".

\section{References}

Borg, H., Stoneman, G.L. 1991. Long-term implications for streamflow of changes in vegetation cover and stand height in regenerating karri stands in South-West Western Australia. - Forest Ecology and Management, 40, 65-73.

Braun-Blanquet, J. 1964. Pflanzensoziologie grundzüge der vegetationsgrenze. (Phytosociology. Broad vegetation science). 3rd ed. Springer, Wien. 865 pp. (In German).

Bréda, N. 2003. Ground-based measurements of leaf area index: a review of methods, instruments and current controversies. - Journal of Experimental Botany, 54, 2403-2417.

Chen, J.M., Cihlar, J. 1995. Plant canopy gap-size analysis theory for improving optical measurements of leaf area index. - Applied Optics, 34, 6211-6222.

Chianucci, F., Chiavetta, U., Cutini, A. 2014a. The estimation of canopy attributes from digital cover photography by two different image analysis methods. - iForest - Biogeosciences and Forestry, 7, 254-258.

Chianucci, F., Cutini, A. 2012. Digital hemispherical photography for estimating forest canopy properties: current controversies and opportunities. iForest - Biogeosciences and Forestry, 5, 290-295 
Chianucci, F., Cutini, A. 2013. Estimation of canopy properties in deciduous forests with digital hemispherical and cover photography. - Agricultural and Forest Meteorology, 168, 130-139.

Chianucci, F., Cutini, A., Corona, P., Puletti, N. 2014b. Estimation of leaf area index in understory deciduous trees using digital photography. - Agricultural and Forest Meteorology, 198, 259-264.

Chianucci, F., Macfarlane, C., Pisek, J., Cutini, A., Casa, R. 2015. Estimation of foliage clumping from the LAI-2000 Plant Canopy Analyzer: effect of view caps. Trees (early view), 29, 355366.

Coll, L., González-Olabarria, J.R., Mola-Yudego, B., Pukkala, T., Messier, C. 2011. Predicting understory maximum shrubs cover using altitude and overstory basal area in different Mediterranean forests. - European Journal of Forest Research, 130, 55-65.

Cutini, A., Chianucci, F., Giannini, T., Manetti, M.C., Salvati, L. 2015. Is anticipated seed cutting an effective option to accelerate transition to high forest in European beech (Fagus sylvati$\mathrm{ca}$ L.) coppice stands? Annals of Forest Sciences (early view), doi:10.1007/s13595-015-0476-7

Decocq, G., Aubert, M., Dupont, F., Alard, D., Saguez, R., Wattez-Franger, A., De, Foucalt, B., DelelisDusollier, A., Bardat, J. 2004. Plant diversity in a managed temperate deciduous forest, understorey response to two silvicultural systems. Journal of Applied Ecology, 41, 1065-1079.

Dodson, E.K., Peterson, D.W., Harrod, R.J. 2008. Understorey vegetation response to thinning and burning restoration treatments in dry conifer forests of the eastern Cascades, USA. - Forest Ecology and Management, 255, 3130-3140.

Eriksson, H.M., Eklundh, L., Kuusk, A., Nilson, T. 2006. Impact of understory vegetation on forest canopy reflectance and remotely sensed LAI estimates. - Remote Sensing of Environment, 103, 408-418.

Jennings, S.B., Brown, N.D., Sheil, D. 1999. Assessing forest canopies and understorey illumination: canopy closure, canopy cover and other measures. - Forestry, 72, 59-73.

Jonckheere, I., Fleck, S., Nackaerts, K., Muys, B., Coppin, P., Weiss, M., Baret, F. 2004. Review of methods for in situ leaf area index determination: Part I. Theories, sensors and hemispherical photography. - Agricultural and Forest Meteorology, 121, 19-35.

Kodar, A., Lang, M., Arumäe, T., Eenmäe, A., Pisek, J., Nilson, T. 2011. Leaf area index mapping with airborne lidar, satellite images and ground measurements in Järvselja VALERI test site. - Forestry Studies / Metsanduslikud Uurimused, 55, 11-32.

Kuusk, A., Lang, M., Nilson, T. 2004. Simulation of the reflectance of ground vegetation in subboreal forests. - Agricultural and Forest Meteorology, 126, 33-46.

Lane, P.N.J., Mackay, S.M. 2001. Streamflow response of mixed-species eucalypt forests to patch cutting and thinning treatments. - Forest Ecology and Management, 143, 131-142.

Lang, M., Kodar, A., Arumäe, T. 2013. Restoration of above canopy reference hemispherical image from below canopy measurements for plant area index estimation in forests. - Forestry Studies / Metsanduslikud Uurimused 59, 13-27.

Macfarlane, C., Hoffman, M., Eamus, D., Kerp, N., Higginson, S., McMurtrie, R., Adams, M.A. 2007. Estimation of leaf area index in eucalypt forest using digital photography. - Agricultural and Forest Meteorology, 143, 176-188.

Macfarlane, C., Lardner, T., Patterson, K., Grigg, A.H. 2010. A new model for predicting understorey leaf area from biomass in eucalypt forest to test the ecohydrological equilibrium theory. - Methods in Ecology and Evolution, 1, 371-379.

Macfarlane, C., Ogden, G. 2012. Automated estimation of foliage cover in forest understorey from digital nadir images. - Methods in Ecology and Evolution, 3, 405-415.

Mclaren, K. 1976. The development of the CIE 1976, $L^{*} a^{*} b^{*}$ uniform colour-space and colourdifference formula. - Journal of the Society of Dyers and Colourists, 92, 338-341.

Messier, C., Parent, S., Bergeron, Y. 1998. Effects of overstory vegetation on the understory light environment in mixed boreal forests. - Journal of Vegetation Science, 9, 511-520.

Nilson, T. 1999. Inversion of gap frequency data in forest stands. - Agricultural and Forest Meteorology, 98, 437-448.

Peltoniemi, J.I., Kaasalainen, S., Näränen, J., Rautiainen, M., Stenberg, P., Smolander, H., Smolander, S., Voipio, P. 2005. BRDF measurement of understory vegetation in pine forests, dwarf shrubs, lichen, and moss. - Agricultural and Forest Meteorology, 94, 343-354.

Pisek, J., Lang, M., Kuusk, J. 2015. A note on suitable viewing configuration for retrieval of forest understory reflectance from multi-angle remote sensing data. - Agricultural and Forest Meteorology, 156, 242-246. 
Rautiainen, M., Mõttus, M., Heiskanen, J., Akujärvi, A., Majasalmi, T., Stenberg, P. 2011. Seasonal reflectance dynamics of common understory types in a northern European boreal forest. - Agricultural and Forest Meteorology, $115,3020-3028$.
Van der Maarel, E. 1979. Trasformation of coverabundance values in phytosociology and its effect on community similarity. - Vegetatio, 39, 97-144.

Received December 6, 2014, revised December 20, 2014, accepted December 29, 2014 